\title{
Is erythropoietin a worthy candidate for traumatic brain injury or are we heading the wrong way? [version 1; peer
}

\section{review: 2 approved]}

\section{Giovanni Grassoํㅜ, Concetta Alafaci², Pietro Ghezzi³}

${ }^{1}$ Section of Neurosurgery, Department of Experimental Biomedicine and Clinical Neurosciences (BIONEC), University of Palermo, Palermo, 90100, Italy

2Department of Neurosurgery, University of Messina, Messina, 98100, Italy

${ }^{3}$ Brighton and Sussex Medical School, Falmer, BN1 9PX, UK

V1 First published: 19 May 2016, 5:911

https://doi.org/10.12688/f1000research.8723.1

Latest published: 19 May 2016, 5:911

https://doi.org/10.12688/f1000research.8723.1

\section{Abstract}

Traumatic brain injury (TBI) is a leading cause of death and disability in the modern society. Although primary prevention is the only strategy that can counteract the primary brain damage, numerous preclinical studies have been accumulated in order to find therapeutic strategies against the secondary damage. In this scenario erythropoietin (EPO) has been shown to be a promising candidate as neuroprotective agent. A recent clinical trial, however, has shown that EPO has not an overall effect on outcomes following TBI thus renewing old concerns. However, the results of a prespecified sensitivity analysis indicate that the effect of EPO on mortality remains still unclear.

In the light of these observations, further investigations are needed to resolve doubts on EPO effectiveness in order to provide a more solid base for tailoring conclusive clinical trials.

\section{Keywords}

Traumatic brain injury , Neuroprotection , Erythropoietin

\section{Open Peer Review \\ Approval Status \\ 1 \\ 2 \\ version 1 \\ 19 May 2016

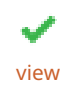

$\checkmark$

1. Hannelore Ehrenreich (D), Max Planck Institute of Experimental Medicine, Göttingen, Germany

Anna-Leena Sirén, University of Würzburg, Würzburg, Germany

2. Alessandro Landi, Sapienza University of Rome, Rome, Italy

Any reports and responses or comments on the article can be found at the end of the article. 
Corresponding author: Giovanni Grasso (giovanni.grasso@unipa.it)

Competing interests: No competing interests were disclosed.

Grant information: PG has received research funds and travel money from Araim Pharma and Warren Pharma, who are developing EPO derivatives with neuroprotective properties.

The funders had no role in study design, data collection and analysis, decision to publish, or preparation of the manuscript.

Copyright: $\odot 2016$ Grasso G et al. This is an open access article distributed under the terms of the Creative Commons Attribution License , which permits unrestricted use, distribution, and reproduction in any medium, provided the original work is properly cited.

How to cite this article: Grasso G, Alafaci C and Ghezzi P. Is erythropoietin a worthy candidate for traumatic brain injury or are we heading the wrong way? [version 1; peer review: 2 approved] F1000Research 2016, 5:911

https://doi.org/10.12688/f1000research.8723.1

First published: 19 May 2016, 5:911 https://doi.org/10.12688/f1000research.8723.1 
Traumatic brain injury (TBI) is one of the major causes of death and disability in our society ${ }^{1}$. TBI can provides heterogeneous effects since, in addition to the primary injury, it is associated with the so-called secondary brain injury where inflammation, excitotoxicity, ischemia, edema participate in worsening the clinical scenario ${ }^{13}$. Several pre-clinical studies have been conducted in order to identify neuroprotective agents able to counteract the secondary tissue damage and improve clinical outcomes ${ }^{8}$. However, translation to the clinical trials has been discouraging and the treatment of TBI remains great challenge worldwide.

In both pre-clinical and clinical studies, erythropoietin (EPO) has been recognized for nearly two decades as a potent neuroprotective agent with a multifaceted, hematopoiesis-independent action profile $^{4}$. The discovery that EPO has neuroprotective functions apart from regulating erythropoiesis ${ }^{3}$ was unexpected and prompted numerous studies showing a protecting role through antiapoptotic, antioxidative and anti-inflammatory, angiogenic and neurotrophic mechanisms ${ }^{7,9}$.

The recent conclusion of the EPO-TBI, double-blind randomized controlled trial ${ }^{10}$, has renewed old concerns. This clinical study was undertaken in 29 centers in seven countries. A total of 606 patients were randomly selected. EPO was given to 308 patients in a dose of 40,000 units subcutaneously, while 298 patients received a placebo, consisting of $0.9 \%$ sodium chloride,. Both EPO and placebo were administered once per week for a maximum of three doses. Randomization was stratified by severity of traumatic brain injury (moderate $v s$. severe) and participating site ${ }^{10}$. The primary outcome, consisting of improvement in the patients' neurological status was measured at 6 months follow-up. It was summarized as a binary midpoint reduction of their extended Glasgow Outcome Scale (GOS-E) level, which was defined as a GOS-E of 1-4 (death, vegetative state, and severe disability) or a GOS-E of 5-8 (moderate disability and good recovery). In addition, mortality, proximal deep venous thrombosis and occurrence of general thrombotic events were assessed as secondary outcomes measures ${ }^{10}$.

The authors found that EPO did not reduce the number of patients with a GOS-E level of 4 or lower, and did not affect the incidence of deep venous thrombosis events.

Overall, the results of this international multicenter randomized placebo-controlled trial suggest that EPO may not be useful in TBI. This result is in contrast with a number of experimental studies suggesting that EPO might improve neurological outcomes following TBI. However, the results of a prespecified sensitivity analysis adjusting for covariates indicate that the effect of EPO on mortality remains to be better investigated. Notably, although in this study EPO did not have an overall effect on survival ${ }^{10}$, when adjusted for illness severity according to the IMPACT-TBI predicted probability of a poor outcome, 6-months mortality was lower in patients given EPO than in those who received placebo.

Although the authors suggest caution in the interpretation of these mortality findings, we believe this question is worthy of note and remains to be addressed. The time window for EPO administration following TBI and its dose regimen are the main arguments. In this study a 24 hours time window and a dose of 40,000 units was chosen. It must be taken into account that earlier preclinical studies showed that recombinant human EPO treatment at a dose of $1000 \mathrm{IU} / \mathrm{kg}$ administered every 8 hours starting following TBI, is effective as neuroprotective agent ${ }^{5}$. The dose used in the study by Nichol and collaborators $^{14}$ is the lowest dosage known to be effective in the experimental settings, and the time for the first administration, an average of 18.6 hours after TBI, would initiate a neuroprotective program in a late secondary damage. The small dose used, time and frequency of administration could contribute to the unfavorable results from this clinical trial. Neuroprotective drugs should be administered as soon as possible and as long as the pathological cascades occur. EPO dose and therapeutic duration were clearly dictated by the concerns on the safety of recombinant human EPO. It is well known that all the information available regarding the safety of EPO comes from its non-neurologic use ${ }^{15}$. Using the information accumulated on EPO safety in patients affected by chronic anemia and put into practice for the management of TBI can be dangerous since the interaction between EPO and various physiologic variables, in addition to drugs commonly used in TBI patients, are unknown.

Additionally, besides its fame of a well-tolerated drug, recent reports of adverse effects associated with the chronic administration of recombinant EPO (i.e. hypertension, hypertensive encephalopathy, seizures, and thrombotic/vascular events) have raised new concerns ${ }^{6}$. Although in experimental and clinical studies, including this randomized trial, no adverse effects during EPO treatment were observed, it is unknown what the effect in patients with a raised hemoglobin concentration would be.

Taken collectively, the findings of this recent clinical trial ${ }^{11}$, together with those from previous randomized studies ${ }^{2,12,14}$, suggest that EPO might decrease mortality in this patient group.

The overall disappointing results of the clinical trials reported over the time could be due to protocol and dosage problems, and one should also bear in mind that it is not always possible to translate animal research to the clinical scenario, which is more complex and less controlled.

More attention should be paid in conducting clinical trials in order to obtain sufficient information regarding therapeutic time window, dosage, duration of therapy and safety. The uncertain results so far obtained put EPO at risk of being discarded as thoroughly as it was initially welcomed as a miracle drug. Meanwhile, better information on the spectrum of biological actions of EPO and the underlying mechanisms would provide a more solid base for tailoring conclusive clinical trials.

In the light of these observations, further investigations are required to resolve such uncertainties especially when issues as optimal dosages, therapeutic time window, and duration of therapy deserve to be clarified. 


\section{Author contributions}

GG prepared the manuscript, CA contributed to the preparation of the manuscript and revision, $\mathrm{PG}$ offered data interpretation.

\section{Competing interests}

No competing interests were disclosed.
Grant information

PG has received research funds and travel money from Araim Pharma and Warren Pharma, who are developing EPO derivatives with neuroprotective properties.

The funders had no role in study design, data collection and analysis, decision to publish, or preparation of the manuscript.
1. Centers for Disease Control and Prevention (CDC): Rates of hospitalization related to traumatic brain injury--nine states, 2003. MMWR Morb Mortal Wkly Rep. 2007; 56(8): 167-170. PubMed Abstract

2. Abrishamkar S, Safavi M, Honarmand A: Effect of erythropoietin on Glasgow Coma Scale and Glasgow Outcome Sale in patient with diffuse axonal injury. $J$ Res Med Sci. 2012; 17(1): 51-56. PubMed Abstract | Free Full Text

3. Brines ML, Ghezzi P, Keenan S, et al.: Erythropoietin crosses the blood-brain barrier to protect against experimental brain injury. Proc Natl Acad Sci U S A. 2000; 97(19): 10526-10531.

PubMed Abstract | Publisher Full Text | Free Full Text

4. Grasso G, Sfacteria A: The many faces of erythropoietin: from erythropoiesis to a rational neuroprotective strategy. Expert Opin Investig Drugs. 2008; 17(10): 1407-1409.

PubMed Abstract | Publisher Full Text

5. Grasso G, Sfacteria A, Meli F, et al:: Neuroprotection by erythropoietin administration after experimental traumatic brain injury. Brain Res. 2007; 1182: 99-105.

PubMed Abstract | Publisher Full Text

6. Jia L, Chopp M, Zhang L, et al.: Erythropoietin in combination of tissue plasminogen activator exacerbates brain hemorrhage when treatment is initiated 6 hours after stroke. Stroke. 2010; 41(9): 2071-2076.

PubMed Abstract | Publisher Full Text | Free Full Text

7. Juul SE, Beyer RP, Bammler TK, et al.: Microarray analysis of high-dose recombinant erythropoietin treatment of unilateral brain injury in neonatal mouse hippocampus. Pediatr Res. 2009; 65(5): 485-492. PubMed Abstract
8. Kabadi SV, Faden Al: Neuroprotective strategies for traumatic brain injury: improving clinical translation. Int J Mol Sci. 2014; 15(1): 1216-1236.

PubMed Abstract | Publisher Full Text | Free Full Text

9. Maiese K, Chong ZZ, Hou J, et al:: Erythropoietin and oxidative stress. Curr Neurovasc Res. 2008; 5(2): 125-142.

PubMed Abstract | Publisher Full Text | Free Full Text

10. Nichol A, French C, Little L, et al.: Erythropoietin in traumatic brain injury (EPO-TBI): a double-blind randomised controlled trial. Lancet. 2015; 386(10012): 2499-506.

PubMed Abstract | Publisher Full Text

11. Nichol A, French C, Little L, et al:: Erythropoietin in traumatic brain injury: study protocol for a randomised controlled trial. Trials. 2015; 16:39. PubMed Abstract | Publisher Full Text | Free Full Text

12. Nirula R, Diaz-Arrastia R, Brasel K, et al.: Safety and efficacy of erythropoietin in traumatic brain injury patients: a pilot randomized trial. Crit Care Res Pract. 2010; 2010: pii: 209848.

PubMed Abstract | Publisher Full Text | Free Full Text

13. Park E, Bell JD, Baker AJ: Traumatic brain injury: can the consequences be stopped? CMAJ. 2008; 178(9): 1163-1170. PubMed Abstract | Publisher Full Text | Free Full Text

14. Robertson CS, Hannay HJ, Yamal JM, et al:: Effect of erythropoietin and transfusion threshold on neurological recovery after traumatic brain injury: a randomized clinical trial. JAMA. 2014; 312(1): 36-47. PubMed Abstract | Publisher Full Text | Free Full Text

15. Tong EM, Nissenson AR: Erythropoietin and anemia. Semin Nephrol. 2001; 21(2): 190-203.

PubMed Abstract 


\section{Open Peer Review}

\section{Current Peer Review Status:}

\section{Version 1}

Reviewer Report 24 May 2016

https://doi.org/10.5256/f1000research.9385.r13936

(C) 2016 Landi A. This is an open access peer review report distributed under the terms of the Creative Commons Attribution License, which permits unrestricted use, distribution, and reproduction in any medium, provided the original work is properly cited.

\section{Alessandro Landi \\ Department of Neurology and Psychiatry, Division of Neurosurgery, Policlinico Umberto I, Sapienza University of Rome, Rome, Italy \\ The title and abstract are exhaustive and clear, appropriate for the content. \\ The study design, methods and analysis are well conduct and appropriate for the topic. \\ The conclusions are relevant in this field. \\ I think that this article is suitable in this form \\ Competing Interests: No competing interests were disclosed. \\ I confirm that I have read this submission and believe that I have an appropriate level of expertise to confirm that it is of an acceptable scientific standard.}

Reviewer Report 23 May 2016

https://doi.org/10.5256/f1000research.9385.r13929

(C) 2016 Ehrenreich $\mathbf{H}$ et al. This is an open access peer review report distributed under the terms of the Creative Commons Attribution License, which permits unrestricted use, distribution, and reproduction in any medium, provided the original work is properly cited.

\section{Hannelore Ehrenreich}

Department of Clinical Neuroscience, Max Planck Institute of Experimental Medicine, Göttingen, Germany

Anna-Leena Sirén

Department of Neurosurgery, University of Würzburg, Würzburg, Germany 


\section{EPO, TBI and some more to say}

In their opinion article, "Is erythropoietin a worthy candidate for traumatic brain injury or are we heading the wrong way?" Giovanni Grasso, Concetta Alafaci and Pietro Ghezzi address a very important topic. Specifically, they summarize and comment on recent formally negative clinical trials on the use of recombinant human erythropoietin (EPO) in traumatic brain injury (TBI). More globally, they lay their fingers in the wound of numerous clinical trials on neuroprotection and neuroregeneration in brain diseases that failed in translation from preclinical studies to the patient. The authors discuss briefly properties and encouraging preclinical studies on EPO, and then raise the most critical issues of the human EPO trials in TBI, mainly the late administration of the first dose, the short duration and low frequency of treatment - all essentially dictated by not too well established safety concerns.

While we fully agree on most of these points, we do not think that the single dose was necessarily too low, as also criticized by the authors. We feel that the dose was likely sufficient but that intravenous rather than subcutaneous dosing should have been used to achieve higher EPO levels in the brain.

We would like to add a few comments that we feel - after 20 years of own experience in translational work on the brain EPO system - are important to consider.

We had to painfully learn ourselves the downstream consequences of pharmaceutical companies and overeager regulatories drawing fast conclusions out of too superficially or not at all analyzed data. This triggered an avalanche of destruction regarding our large EPO stroke multicenter trial where severe treatment violations of stroke patients in several centers (totally independent of the study medication) explained the outcome rather than EPO ${ }^{1}$. In fact, careful subpopulation analysis of all dead patients revealed that several relevant baseline characteristics (i.e. data obtained before administration of any study medication) were significantly different between groups, always in disadvantage of the EPO group. Most importantly, upon inclusion (before any study drug application), intent-to-treat non-rtPA receiving EPO patients who died suffered from much severer strokes as compared to placebo patients (NIHSS day 1: $20.4 \pm 5.4$ versus $13.3 \pm 4.9 ; p=0.003$ ). This highly significant prediction of a worse outcome explains the twofold higher very early death rate in the EPO group (http://www.epo-study.de/index_eng.html).

Unfortunately, the premature jumping to conclusions regarding the EPO stroke trial influenced also one of the TBI trials discussed here: The authors write that "there was concern by the FDA that the initial regimen of 3 daily doses of EPO would impose a greater risk of death. This concern resulted in a modified study design after approximately one-third of the patients had been enrolled in the trial. We did not detect an increased mortality rate with the EPO dose regimen, and the neurological outcome results were more promising than with the subsequent regimen. However, because the original dose regimen was stopped early, the numbers of cases are too small to draw any conclusions"'?

Even though safety is undoubtedly an important issue, we have to reduce the incredible arrogance of dismissing any trial that shows 'just signals' of benefit. How can we expect more in an initial translational step? Being aware that there are no neuroprotective/neuroregenerative treatments out for conditions as frequent and detrimental as stroke or TBI, it would be time to work hard on any positive signals rather than 'throw the baby out with the bathwater'. 
And clearly, both TBI trials ${ }^{2,3}$ show such signals. Regarding stroke, not only the first EPO trial was obviously promising ${ }^{4}$, but also the retrospective analysis of patients from Hannover, the most efficiently recruiting center of the second EPO stroke trial $^{5}$, made the beneficial effect of EPO in stroke again very obvious.

Getting back to the opinion paper by Grasso and colleagues, longer treatment duration - over many weeks - may ultimately disclose the benefit of EPO also for TBI much stronger. Clinical studies on EPO in chronic brain diseases (schizophrenia, multiple sclerosis, major and bipolar depression) with extended treatment using high dose EPO over many weeks showed consistently advantageous effects on cognition, motor function, and even reduction of brain matter loss. All these findings were in absence of any appreciable side effects ${ }^{6-11}$. Of course, in all clinical studies, the quality of patient care including alert follow-up of individual patients at all times is mandatory 12 .

Work on EPO indications outside the hematopoietic system has been difficult ever since. Large studies would be needed with adequate funding. Funding agencies do not provide enough money and direct requests for financing to industry. Industry has not been supportive due to expired EPO patents and many EPO biosimilar producers popping up, increasing the risk of 'off-label-use'. Protection of the extremely lucrative anemia market includes avoiding the risk of additional side effects in new indications.

EPO is a potent growth factor, not a miracle drug, and it is not a causal treatment or cure of brain diseases but it may improve their outcome. Even though doping is an unpleasant chapter in itself, it may be seen in the present context as one of the most convincing field studies ever regarding efficiency of EPO. Who would invest huge amounts of money over decades and risk to be caught by controllers and convicted if EPO were not extremely effective?

Despite all frustrations and disappointments: We have to keep trying to understand how EPO acts in the brain and to ultimately exploit this knowledge for the benefit of our patients. Some novel and surprising insight, lending further support to the use of EPO for neuroprotective and neuroregenerative treatment of brain diseases, comes from recent studies showing that EPO increases the number of neurons and oligodendrocytes in the hippocampus by driving preexisting precursors to differentiate ${ }^{13}$, or from work reporting EPO effects on synaptic plasticity ${ }^{14}$, 15.

\section{References}

1. Ehrenreich $\mathrm{H}$, Weissenborn $\mathrm{K}$, Prange $\mathrm{H}$, Schneider $\mathrm{D}$, et al.: Recombinant human erythropoietin in the treatment of acute ischemic stroke.Stroke. 2009; 40 (12): e647-56 PubMed Abstract I Publisher Full Text

2. Robertson CS, Hannay HJ, Yamal JM, Gopinath S, et al.: Effect of erythropoietin and transfusion threshold on neurological recovery after traumatic brain injury: a randomized clinical trial.JAMA. 2014; 312 (1): 36-47 PubMed Abstract | Publisher Full Text

3. Nichol A, French C, Little L, Haddad S, et al.: Erythropoietin in traumatic brain injury (EPO-TBI): a double-blind randomised controlled trial.Lancet. 2015; 386 (10012): 2499-506 PubMed Abstract | Publisher Full Text

4. Ehrenreich $\mathrm{H}$, Hasselblatt M, Dembowski C, Cepek L, et al.: Erythropoietin therapy for acute stroke is both safe and beneficial.Mol Med. 2002; 8 (8): 495-505 PubMed Abstract

5. Worthmann $\mathrm{H}$, Martens-Lobenhoffer J, Joumaah $\mathrm{M}$, Li N, et al.: Asymmetric dimethylarginine in 
response to recombinant tissue-type plasminogen activator and erythropoietin in acute stroke. Stroke. 2013; 44 (8): 2128-33 PubMed Abstract | Publisher Full Text

6. Ehrenreich H, Fischer B, Norra C, Schellenberger F, et al.: Exploring recombinant human erythropoietin in chronic progressive multiple sclerosis.Brain. 2007; 130 (Pt 10): 2577-88 PubMed Abstract | Publisher Full Text

7. Ehrenreich $\mathrm{H}$, Hinze-Selch D, Stawicki S, Aust C, et al.: Improvement of cognitive functions in chronic schizophrenic patients by recombinant human erythropoietin.Mol Psychiatry. 2007; 12 (2): 206-20 PubMed Abstract | Publisher Full Text

8. Wüstenberg T, Begemann M, Bartels C, Gefeller O, et al.: Recombinant human erythropoietin delays loss of gray matter in chronic schizophrenia.Mol Psychiatry. 2011; 16 (1): 26-36, 1 PubMed Abstract | Publisher Full Text

9. Miskowiak KW, Ehrenreich H, Christensen EM, Kessing LV, et al.: Recombinant human erythropoietin to target cognitive dysfunction in bipolar disorder: a double-blind, randomized, placebo-controlled phase 2 trial.J Clin Psychiatry. 2014; 75 (12): 1347-55 PubMed Abstract | Publisher Full Text

10. Miskowiak KW, Vinberg M, Christensen EM, Bukh JD, et al.: Recombinant human erythropoietin for treating treatment-resistant depression: a double-blind, randomized, placebo-controlled phase 2 trial.Neuropsychopharmacology. 2014; 39 (6): 1399-408 PubMed Abstract | Publisher Full Text 11. Miskowiak KW, Vinberg M, Macoveanu J, Ehrenreich $\mathrm{H}$, et al.: Effects of Erythropoietin on Hippocampal Volume and Memory in Mood Disorders.Biol Psychiatry. 2015; 78 (4): 270-7 PubMed Abstract | Publisher Full Text

12. Sirén AL, Fasshauer T, Bartels $\mathrm{C}$, Ehrenreich $\mathrm{H}$ : Therapeutic potential of erythropoietin and its structural or functional variants in the nervous system.Neurotherapeutics. 2009; 6 (1): 108-27 PubMed Abstract | Publisher Full Text

13. Hassouna I, Ott C, Wüstefeld L, Offen N, et al.: Revisiting adult neurogenesis and the role of erythropoietin for neuronal and oligodendroglial differentiation in the hippocampus.Mol Psychiatry . 2016. PubMed Abstract | Publisher Full Text

14. Almaguer-Melian W, Mercerón-Martínez D, Delgado-Ocaña S, Pavón-Fuentes N, et al.: EPO induces changes in synaptic transmission and plasticity in the dentate gyrus of rats.Synapse. 2016; 70 (6): 240-52 PubMed Abstract | Publisher Full Text

15. Mengozzi M, Cervellini I, Villa P, Erbayraktar Z, et al.: Erythropoietin-induced changes in brain gene expression reveal induction of synaptic plasticity genes in experimental stroke.Proc Natl Acad Sci U S A. 2012; 109 (24): 9617-22 PubMed Abstract | Publisher Full Text

Competing Interests: No competing interests were disclosed.

We confirm that we have read this submission and believe that we have an appropriate level of expertise to confirm that it is of an acceptable scientific standard. 
The benefits of publishing with F1000Research:

- Your article is published within days, with no editorial bias

- You can publish traditional articles, null/negative results, case reports, data notes and more

- The peer review process is transparent and collaborative

- Your article is indexed in PubMed after passing peer review

- Dedicated customer support at every stage

For pre-submission enquiries, contact research@f1000.com 